\title{
Which Management Level Decides To Outsource The Distribution Function?
}

Michael Cant, University of South Africa, South Africa

Louise Van Scheers, University of South Africa, South Africa

\begin{abstract}
Outsourcing is one of the widest used methods of facilities management employed by organisations for doing business in today's global economy which requires exceptional skills from management in order to be competitive and to have an advantage over competitors; and this situation is getting even more demanding. The main purpose of the research is to evaluate consensus amongst the different levels of management to outsource the distribution function at a South African steel retailer.

The research survey was done in the form of a questionnaire utilising statements with a quantitative approach regarding six important aspects relating to the outsourcing concept of noncore business activities linked to the distribution operations of a steel company. The population selected consisted of the first three levels of management across all six of the business units. Analysis of the data was done with the statistical package of social sciences SPSS and the applied pedometric techniques, such as Chi-square and ANOVA. Findings and results from the analysis indicate that management, in general, is positive toward adopting outsourcing as a tool to assist them in business operations, but there seems to be a significant difference of opinion between middle and top management regarding the impact of the outsourcing concept.
\end{abstract}

Keywords: Outsourcing; Distribution Function; Retailer; Different Levels of Management; Top; Senior and Middle Management Levels

\section{INTRODUCTION}

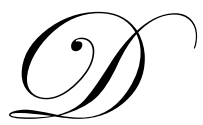

riven by political and economic dynamic changes, facilities management was borne to enable reacting to change. Doing business in today's global economy requires exceptional skills from management in order to be competitive, and to have a specific competitive advantage over competitors is even more demanding. One of the widest used methods of facilities management deployed by organisations is that of outsourcing in various forms (i.e., IT, HR, Distribution, Warehousing, etc.) for various different reasons (i.e., reduce costs, improve quality, focus on core business, etc.). In order for outsourcing to be successful, it needs to add benefits to profits, efficiency or effectiveness ethics. Outsourcing assists management in gaining a competitive advantage over competitors within their specific industries as part of their organizational strategies and developing or strengthening core competencies at the same time (Taplin, 2008). Outsourcing the distribution function involves hiring a third party to store and distribute products through its national or international distribution network. This party provides the staff, warehouses, distribution centre and transportation fleet. Distribution is not the core competency for this steel retailer; therefore, management decided to outsource this function to allow them to focus on mission-critical activities. However, it seems that there are differences in consensus amongst the different levels of management to outsource this function.

This research aims to evaluate whether there is consensus amongst the different levels of management to outsource the distribution function at a South African steel retailer. The steel company is a privately owned industrial management group which is represented in the UK, Australia, USA and South Africa where it manages a diverse portfolio of small-to-medium sized enterprises focused on addressing niche segments. 


\section{PROBLEM STATEMENT}

Following the changes in the South African political dispensation and the launch of the Broad-based Black Economic Empowerment policy, organizations were forced to revisit their structures and policies. A score card was devised whereby organizations earn points in different categories of the company; i.e., shareholding, management structure, supply partners, development \& training programs, upliftment programs, welfare participation contributions, etc. This will categorise an organisation in terms of what level of Black Economic Empowerment contributor the company is for doing business. Fueled further with the economic recession globally, organizations faced downscaling, retrenchments and restructuring the way they used to do business in order to create sustainability and compliance. These changes forced the steel retailer to outsource some of the non-core functions to stay competitive. One of the various outsourcing options implemented by the steel retailer was to break down the head office structure by relocating the finance-related functions' resources to business units for better control and optimisation and also outsourcing of the distribution function to an external company. This was, however, left to the demise of each business unit manger's own decision instead of a group strategy to which company they will be outsourcing and on what basis this will be structured.

\section{AIM AND OBJECTIVES}

The main purpose of this research is to evaluate differences in consensus amongst the different levels of management to outsource the distribution function at a South African steel retailer. The objectives are to:

- Establish whether there is consensus between top, senior and middle management on outsourcing the distribution function

- Gather perceptions on views of the top, senior and middle management regarding outsourcing the distribution function

The following hypnoses were formulated:

$\mathbf{H}_{1}$ : There is a positive correlation between the general importance of outsourcing and the opinion of the organization toward outsourcing of distribution.

$\mathbf{H}_{\mathbf{2}}$ : There is a positive correlation between the organization's opinion toward outsourcing and the potential improvement that outsourcing can bring.

$\mathbf{H}_{3}$ : There is a positive correlation between the improvement of the organization and the financial and revenue implications to the organization.

$\mathbf{H}_{\mathbf{4}}$ : There is positive correlation between the financial and revenue reasons and the cost of outsourcing distribution.

$\mathbf{H}_{\mathbf{5}}$ : There is a positive correlation between the cost and the risks associated with outsourcing.

H6 $_{6}$ : There is a positive correlation between the risks and the level of satisfaction with the current situation.

$\mathbf{H}_{7}$ : There is a positive correlation between cost driven reasons to outsource and level of satisfaction with the current situation.

\section{RESEARCH METHODOLOGY}

A quantitative approach was used with a survey questionnaire as the method for collecting the data between 15 October and 15 November, 2010. The design for this research will be a quantitative approach and the instrument available for data collection will be a survey questionnaire. The population for the research survey is the South African steel retailer and the sample consists of the three different levels of management classified as Level 1, Level 2 and Level 3 as per the Organogram of the organization. Table 1 represents a breakdown of the management 
classification, the total participants involved in the research, and the number of respondents within the three different levels.

Table 1: Research Participants and Classification

\begin{tabular}{|l|c|c|}
\hline \multicolumn{1}{|c|}{ Management Classification } & Total Participants & Number of Respondents \\
\hline Level 1 (Top Management) & 7 & 7 \\
\hline Level 2 (Senior Management) & 21 & 21 \\
\hline Level 3 (Middle Management) & 33 & 33 \\
\hline Total & $\mathbf{6 1}$ & $\mathbf{6 1}$ \\
\hline
\end{tabular}

Source: The steel retailer S.A. Outsourcing Survey

Level 1 participants consist of top management in the group (all directors on the board) whose responsibility mainly relates to strategic decision-making within the group and/or business unit.

Level 2 participants represent the top management within the business units (directors and senior managers at the business unit level) and whose responsibility mainly relates to strategic and/or operational decision-making for the specific business unit.

Level 3 participants represent the senior management within the business units and whose responsibilities mainly relate to operational decision-making for those business units.

The questionnaire comprises 37 statements that revolve around six important aspects of the outsourcing phenomenon. The 37 statements of the questionnaire measure the opinions of the three levels of management based on a 5-point balanced Likert-type scale.

\section{LITERATURE REVIEW}

Different organizations will outsource different operations which could include mostly non-core functional areas; i.e., IT, Distribution, Warehousing, etc., relevant to their specific organizational needs. There are different models available in order to assist management in their decision-making process for the specific function to be outsourced. Outsourcing is the process of purchasing goods or services previously produced within the company on specification from an external supplier (Mol, 2004:585). Outsourcing can involve the transfer of an entire business function to a supplier or the transfer of some activities associated with the function whilst some are kept in-house. Wisner, Tan and Leon (2009:116) use the term co-sourcing for the partially outsourcing of functions or activities. We also find that vertical integration or disintegration is associated with outsourcing. Vertical disintegration is concerned with the decision on whether to perform an activity internally or source it from the outside. Another term that is often used in a manufacturing context is 'make-or-buy' (McIvor, 2005:7).

\section{Outsourcing}

There is no certainty as to when outsourcing (the concept of employing specialized skills from outside the company to perform a specific function for the organization for a period of time or indefinitely) started, but this term was invented by the Information Systems Trade Press during the late 1980's. The term was used to describe the trend that developed amongst large organizations to transfer their information systems to external service providers (Greaver, 1999). According to Roman Seidl (2007), emerging research was seen to have examined several aspects of outsourcing and its impact on "why" and "how". The primary reason for outsourcing is found to have changed from cost cutting to focusing on their core business. A possible assumption is that today's companies analyse and categorise their processes according to core and non-core processes; consequently, the sharpened company focus has become the main reason for outsourcing.

One of Porter's Generic Strategies (Porter, 1980) is access to lower costs, which can be achieved through optimal outsourcing and vertical integration if executed smartly with the necessary research, investigations and careful selection of sourcing partners. Porter (Porter, 1998) also recognises the value chain as useful in outsourcing 
decisions. By understanding the linkages between activities, it can lead to more optical make-or-buy decisions that can result in either a cost advantage or a differentiation advantage. Readings from Bendor-Samuel (2000) make it clear that all over the world companies are facing increasingly competitive markets and need to improve organizational operations to stay ahead of competitors, and he maintains that outsourcing of non-core activities is the main alternative management tool available to achieve this goal.

\section{Reasons to Outsource}

From the researcher's various readings - Greaver (1999), Badenhorst-Weis and Nel (2008), Rosenberg \& Macaulay (1993), IAOP (2009a), Dimension Data (2009), Atos Origin (2004), Think180 (2008c) \& Seidl (2007) the following summary of reasons were identified but are not limited to these:

- $\quad$ Focusing in-house resources on more strategic business issues and/or new technology and systems

- Increased competition, need to improve competitive advantage

- $\quad$ Globalization of markets

- $\quad$ Reorganization and streamlining

- Availability of necessary skilled workforce

Different organizations will have different needs and in-house skill sets for variation in reasons and methods for outsourcing. Some organizations will also make use of in-sourcing as opposed to outsourcing for a period of time, depending on the requirements and the level of in-house skills.

\section{RESEARCH FINDINGS}

\section{Overall Summary of Management Mean Score Analysis}

Table 2 reflects the overall situation with the seven grouped categories (Factors) pertaining to the outsourcing concept at a South African steel retailer, displaying the mean averages obtained by each management group for each of the seven factors and an overall measure of the factors. From the data in Table 2 , it becomes evident that Top Management is the least positive with outsourcing, but not at any significance levels. Further investigation will explore more in-depth analysis to interpret these summarised results more intensely.

Table 2: Overall Summary of Management Mean Score Analysis

\begin{tabular}{|c|c|c|c|c|c|}
\hline \multirow{2}{*}{ Statement } & \multirow{2}{*}{ Survey Questionnaire Factor } & \multicolumn{4}{|c|}{ Levels of Management } \\
\hline & & Middle & Senior & Top & Total \\
\hline $1-4$ & General importance of outsourcing. & 3.648 & 3.524 & 3.143 & 3.546 \\
\hline $5-9$ & Organizationally driven reasons to outsource. & 3.819 & 3.848 & 3.743 & 3.820 \\
\hline $10-15$ & Improvement driven reasons to outsource. & 3.630 & 3.389 & 3.024 & 3.475 \\
\hline $16-19$ & $\begin{array}{l}\text { Financial and Revenue driven reasons to } \\
\text { outsource. }\end{array}$ & 3.742 & 3.607 & 3.321 & 3.646 \\
\hline $20-22$ & Cost driven reasons to outsource. & 3.542 & 3.810 & 3.191 & 3.594 \\
\hline $23-32$ & $\begin{array}{l}\text { Reasons not to outsource and risks } \\
\text { associated with outsourcing. }\end{array}$ & 3.680 & 3.571 & 3.543 & 3.626 \\
\hline $33-37$ & Level of satisfaction with current situation. & 3.350 & 3.029 & 2.829 & 3.177 \\
\hline
\end{tabular}

Source: The steel retailer S.A. Outsourcing Survey 


\section{Summary of Quantitative Data}

Statistically spoken, a Cronbach value of between 0.6 and 0.8 is of an acceptable level (the internal consistency is adequate) and a value of between 0.8 and 1.0 is considered good. From Table 3, it is apparent that factor 2 of the data analysed is just below the minimum requirement due to the low mean scores of questions 5 to 7 , which is a concern for the results of this research.

Table 3: Cronbach's Alpha Coefficient

\begin{tabular}{|c|c|c|c|c|}
\hline Statement & $N$ & $\begin{array}{c}\text { Cronbach's } \\
\text { Alpha } \\
\text { Cofficient }\end{array}$ & Factor & $\begin{array}{c}\text { Overall } \\
\text { Cronbach's } \\
\text { Alpha Coeff }\end{array}$ \\
\hline 1 & 60 & 0.469 & \multirow{4}{*}{ F1 } & \multirow{4}{*}{0.657} \\
\hline 2 & 60 & 0.467 & & \\
\hline 3 & 60 & 0.711 & & \\
\hline 4 & 60 & 0.631 & & \\
\hline 5 & 60 & 0.433 & \multirow{5}{*}{$\mathrm{F} 2$} & \multirow{5}{*}{0.556} \\
\hline 6 & 60 & 0.474 & & \\
\hline 7 & 60 & 0.44 & & \\
\hline 8 & 60 & 0.537 & & \\
\hline 9 & 60 & 0.574 & & \\
\hline 10 & 60 & 0.533 & \multirow{6}{*}{ F3 } & \multirow{6}{*}{0.633} \\
\hline 11 & 60 & 0.633 & & \\
\hline 12 & 60 & 0.625 & & \\
\hline 13 & 60 & 0.633 & & \\
\hline 14 & 60 & 0.521 & & \\
\hline 15 & 60 & 0.563 & & \\
\hline 16 & 60 & 0.454 & \multirow{4}{*}{ F4 } & \multirow{4}{*}{0.624} \\
\hline 17 & 60 & 0.586 & & \\
\hline 18 & 60 & 0.594 & & \\
\hline 19 & 60 & 0.559 & & \\
\hline 20 & 60 & 0.514 & \multirow{3}{*}{ F5 } & \multirow{3}{*}{0.68} \\
\hline 21 & 60 & 0.711 & & \\
\hline 22 & 60 & 0.506 & & \\
\hline 23 & 60 & 0.807 & \multirow{10}{*}{ F6 } & \multirow{10}{*}{0.834} \\
\hline 24 & 60 & 0.821 & & \\
\hline 25 & 60 & 0.808 & & \\
\hline 26 & 60 & 0.806 & & \\
\hline 27 & 60 & 0.808 & & \\
\hline 28 & 60 & 0.8 & & \\
\hline 29 & 60 & 0.85 & & \\
\hline 30 & 60 & 0.821 & & \\
\hline 31 & 60 & 0.818 & & \\
\hline 32 & 60 & 0.828 & & \\
\hline 33 & 60 & 0.807 & \multirow{5}{*}{$\mathrm{F} 7$} & \multirow{5}{*}{0.831} \\
\hline 34 & 60 & 0.755 & & \\
\hline 35 & 60 & 0.776 & & \\
\hline 36 & 60 & 0.789 & & \\
\hline 37 & 60 & 0.856 & & \\
\hline
\end{tabular}

Source: The steel retailer S.A. Outsourcing Survey 


\section{Correlations between the Seven Factors}

Correlation is a measure of linear association between 2 variables. A correlation coefficient of 1 indicates perfect correlation and a correlation coefficient of 0 indicates a total lack of any linear association. In Table 4, the highlighted correlations indicate where the correlation is significant between two factors of the analysis; i.e., the correlation between Financial and Revenue Driven Reasons to outsource and that of General Importance of Outsourcing is 0.019 , which is below the level of 0.05 and is therefore significantly different from " 0 ".

Table 4: Correlations between the 7 Factors

In the table below the 7 factors were correlated with each other in an attempt to determine the existence of linear relationships.

\begin{tabular}{|c|c|c|c|c|c|c|c|c|}
\hline \multicolumn{9}{|c|}{ Correlations } \\
\hline & & F1 & F2 & F3 & $\mathbf{F 4}$ & F5 & F6 & F7 \\
\hline \multirow{3}{*}{$\begin{array}{l}\text { General } \\
\text { importance of } \\
\text { outsourcing }\end{array}$} & $\begin{array}{l}\text { Pearson } \\
\text { Correlation }\end{array}$ & 1 & .238 & $.481^{20}$ & $.303^{\circ}$ & -.092 & .056 & .174 \\
\hline & Sig. (2-tailed) & & .067 & .000 & .019 & .486 & .672 & .184 \\
\hline & $\mathrm{N}$ & 60 & 60 & 60 & 60 & 60 & 60 & 60 \\
\hline \multirow{3}{*}{$\begin{array}{l}\text { Organizationally } \\
\text { driven reasons } \\
\text { to outsource }\end{array}$} & Pearson & .238 & 1 & $.365^{-1}$ & .170 & -.054 & -.185 & .159 \\
\hline & Sig. (2-tailed) & .067 & & .004 & .194 & .684 & .156 & .225 \\
\hline & $N$ & 60 & 60 & 60 & 60 & 60 & 60 & 60 \\
\hline \multirow{3}{*}{$\begin{array}{l}\text { Improvement } \\
\text { driven reasons } \\
\text { to outsource }\end{array}$} & $\begin{array}{l}\text { Pearson } \\
\text { Correlation }\end{array}$ & $.481^{.4}$ & $.365^{4}$ & 1 & $445^{-1}$ & .179 & \begin{tabular}{l|}
-.091 \\
\end{tabular} & $.287^{\circ}$ \\
\hline & Sig. (2-tailed) & .000 & .004 & & .000 & .172 & .489 & .026 \\
\hline & $N$ & 60 & 60 & 60 & 60 & 60 & 60 & 60 \\
\hline \multirow{3}{*}{$\begin{array}{l}\text { Financial and } \\
\text { Revenue driven } \\
\text { reasons to } \\
\text { outsource }\end{array}$} & $\begin{array}{l}\text { Pearson } \\
\text { Correlation }\end{array}$ & $.303^{4}$ & .170 & $.445^{.1}$ & 1 & .176 & .055 & $.351^{\prime \prime}$ \\
\hline & Sig. (2-tailed) & .019 & .194 & .000 & & .178 & .674 & .006 \\
\hline & $N$ & 60 & 60 & 60 & 60 & 60 & 60 & 60 \\
\hline \multirow{3}{*}{$\begin{array}{l}\text { Cost driven } \\
\text { reasons to } \\
\text { outsource }\end{array}$} & $\begin{array}{l}\text { Pearson } \\
\text { Correlation }\end{array}$ & & -.054 & .179 & .176 & 1 & .041 & -.016 \\
\hline & Sig. (2-tailed) & .486 & .684 & .172 & .178 & & .755 & .906 \\
\hline & $\mathrm{N}$ & 60 & 60 & 60 & 60 & 60 & 60 & 60 \\
\hline \multirow{3}{*}{$\begin{array}{l}\text { Reasons not to } \\
\text { outsource and } \\
\text { risks associated } \\
\text { with outsourcing }\end{array}$} & $\begin{array}{l}\text { Pearson } \\
\text { Correlation }\end{array}$ & .056 & -.185 & -.091 & .055 & .041 & 1 & -.082 \\
\hline & Sig. (2-tailed) & .672 & .156 & .489 & .674 & .755 & & .534 \\
\hline & $N$ & 60 & 60 & 60 & 60 & 60 & 60 & 60 \\
\hline \multirow{3}{*}{$\begin{array}{l}\text { Level of } \\
\text { satisfaction with } \\
\text { current situation }\end{array}$} & $\begin{array}{l}\text { Pearson } \\
\text { Correlation }\end{array}$ & .174 & .159 & $.287^{1}$ & $.351^{\circ}$ & -.016 & -.082 & 1 \\
\hline & Sig. (2-tailed) & .184 & .225 & .026 & .006 & .906 & .534 & \\
\hline & $\mathrm{N}$ & 60 & 60 & 60 & 60 & 60 & 60 & 60 \\
\hline
\end{tabular}

Source: The steel retailer S.A. Outsourcing Survey

\section{HYPOTHESES TESTING}

$\mathbf{H}_{\mathbf{1}}$ : There is a positive correlation between the general importance of outsourcing and the opinion of the organization toward outsourcing of distribution.

General Importance of outsourcing (F1) $\rightarrow$ Organizationally Driven reason to outsource (F2) $=0.067$

The correlation between F1 and F2 is closer to zero and indicates a lack of linear association. This indicates that the organization, as a whole, does not deem outsourcing to be of general importance. The results show that the $\mathrm{H}_{1}$ hypothesis was rejected and the alternative is accepted:

Ha $_{1}$ : There is a Negative correlation between the general importance of outsourcing and the opinion of the organization toward outsourcing of distribution. 
Middle and senior management agree more than top management to the general importance of outsourcing because middle management, especially, has to handle the distribution function.

$\mathbf{H}_{2}$ : There is a positive correlation between the organization's opinion toward outsourcing and the potential improvement that outsourcing can bring.

Organizationally Driven reason to outsource $(\mathrm{F} 2) \rightarrow$ Improvement driven reasons to outsource $(\mathrm{F} 3)$ $=0.004$

The correlation between F2 and F3 is closer to zero and indicates a lack of linear association. Generally, the organization feels that outsourcing won't improve their business. The results show that the $\mathrm{H}_{2}$ hypothesis is rejected, thus accepting the alternative:

Ha$_{2}$ : There is a negative correlation between the organizations opinion toward outsourcing and the potential improvement that outsourcing can bring.

Middle and senior management believe that outsourcing is important but won't improve the organization.

Middle and top management are more involved with the distribution and believe that outsourcing the distribution function will definitely improve the organization.

$\mathbf{H}_{3}$ : There is a positive correlation between the improvement of the organization and the financial and revenue implications to the organization.

Improvement-driven reasons to outsource $(\mathrm{F} 3) \rightarrow$ Financial and revenue-driven reasons to outsource $(\mathrm{F} 4)$ $=0.000$

The correlation between F3 and F4 is at the lowest point of the scale, indicating a total lack of linear association and meaning that there is a complete lack of association between the improvement of the business and the financial and revenue implications. This indicates that the $\mathrm{H}_{3}$ hypothesis is rejected and the alternative is accepted:

Ha $:$ There is a negative correlation between the improvement of the organization and the financial and revenue implications to the organization.

Top management obviously wants to improve the state of the organization, but they are not willing to spend money on outsourcing distribution.

Top management's opinion is very neutral toward the statement that outsourcing will cause general improvement, while middle management believes that it will make a significant difference. Top management are involved with the management of the resources (financial and other) and they are not involved with the operational functions.

$\mathbf{H}_{\mathbf{4}}$ : There is positive correlation between the financial and revenue reasons and the cost of outsourcing distribution.

Financial and revenue-driven reasons to outsource $(\mathrm{F} 4) \rightarrow$ Cost-driven reasons to outsource (F5) $=0.176$

The correlation between F4 and F5 is closer to zero and indicates a lack of linear association. There is little linear association between the cost and financial and revenue-driven reasons. Therefore, the $\mathrm{H}_{4}$ hypothesis is rejected and the alternative is accepted: 
Ha: There is negative correlation between the financial and revenue reasons and the cost of outsourcing distribution.

Middle management is of the opinion that there are positive financial consequences to spending money on outsourcing distribution, while top management is not willing to spend money on outsourcing as they believe it is better to spend the money on something else.

$\mathbf{H}_{5}: \quad$ There is a positive correlation between the cost and the risks associated with outsourcing.

Cost-driven reasons to outsource (F5) $\rightarrow$ Reasons not to outsource and risks associated with outsourcing $(\mathrm{F} 6)=0.755$

The correlation between F5 and F6 is close to one and therefore indicates a more perfect linear association. The belief is that it costs more not to outsource. This indicates that it is more cost effective to outsource distribution than to handle it internally. The results show that the $\mathrm{H}_{5}$ hypothesis was accepted. Middle, senior and top management opinions are very close together and are above average toward the cost involved not outsourcing distribution.

$\mathbf{H}_{6}$ : There is a positive correlation between the risks and the level of satisfaction with the current situation.

Reasons not to outsource and risks associated with outsourcing (F6) $\rightarrow$ Level of satisfaction with current situation $(\mathrm{F} 7)=0.534$

The correlation between F6 and F7 is close to the halfway mark, but it indicates a closer-to-perfect linear association. There is an above average opinion toward the risks involved with outsourcing and the level of satisfaction with the current situation. They are a little hesitant to take on risks to improve their current situation, which indicates that the $\mathrm{H}_{6}$ hypothesis can be accepted. Top management is not satisfied with the current situation, but they are a little hesitant to take on risks associated with outsourcing. The two factors that have the most perfect linear association with each other are F7 and F5.

$\mathbf{H}_{7}$ : There is a positive correlation between cost driven reasons to outsource and level of satisfaction with the current situation.

F5 $=$ Cost driven reasons to outsource $\rightarrow$ F7 $=$ Level of satisfaction with current situation $=0.906$

The general feeling is that they want to improve the current situation but keep the costs to a minimum. The two factors with the most lack of linear association with each other are F3 and F4.

\section{Analysis Pertaining to the Three Levels of Management}

Ideally, the mean scores should have a low standard deviation - the Levene Test bigger than 0.05 and the ANOVA bigger than 0.05 .

\section{General Importance of Outsourcing}

The data in Table 5 reflects an overall mean score of 3.5458 with a standard deviation of 0.67568 . Levene's test for homogeneity of variances with $\mathrm{P}=0.859$ versus 0.05 (no significant differences in variances) and ANOVA significance value $\mathrm{P}=0.199$ versus the alpha value of 0.05 (Management Level has no significance upon the mean score of Factor 1). The level of dispersion within the management levels makes it difficult to come to any conclusions as the standard deviation is too high. 
Table 5: General Importance of Outsourcing Analysis by Management Level

\begin{tabular}{|c|c|c|c|c|c|c|c|c|}
\hline \multicolumn{9}{|c|}{ 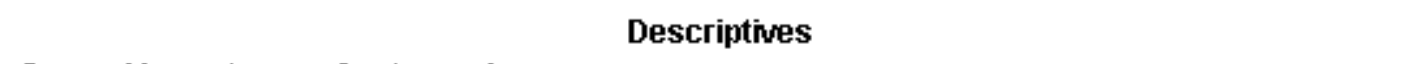 } \\
\hline & \multirow[b]{2}{*}{$\mathrm{N}$} & \multirow[b]{2}{*}{ Mean } & \multirow[b]{2}{*}{$\begin{array}{c}\text { Std. } \\
\text { Deviation }\end{array}$} & \multirow[b]{2}{*}{$\begin{array}{l}\text { Std. } \\
\text { Error }\end{array}$} & \multicolumn{2}{|c|}{$95 \%$ Confidence } & \multirow[b]{2}{*}{ Min } & \multirow[b]{2}{*}{ Max } \\
\hline & & & & & $\begin{array}{l}\text { Lower } \\
\text { Bound }\end{array}$ & $\begin{array}{l}\text { Upper } \\
\text { Bound }\end{array}$ & & \\
\hline Middle Management & 32 & 3.6484 & .65334 & .11550 & 3.4129 & 3.8840 & 2.00 & 4.75 \\
\hline Senior Management & 21 & 3.5238 & .62202 & .13574 & 3.2407 & 3.8069 & 2.50 & 4.75 \\
\hline Top Management & 7 & 3.1429 & .86431 & .32668 & 2.3435 & 3.9422 & 2.00 & 4.75 \\
\hline Total & 60 & 3.5458 & .67568 & .08723 & 3.3713 & 3.7204 & 2.00 & 4.75 \\
\hline
\end{tabular}

Test of Homogeneity of Variances

\begin{tabular}{|c|c|c|c|}
\hline Levene Statistic & df1 & $\mathrm{df} 2$ & Sig. \\
\hline .153 & 2 & 57 & .859 \\
\hline
\end{tabular}

ANOVA

\begin{tabular}{|l|r|r|r|r|r|}
\hline & \multicolumn{1}{|c|}{$\begin{array}{c}\text { Sum of } \\
\text { Squares }\end{array}$} & df & $\begin{array}{c}\text { Mean } \\
\text { Square }\end{array}$ & F & Sig. \\
\hline Between Groups & 1.484 & 2 & .742 & 1.661 & .199 \\
Within Groups & 25.453 & 57 & .447 & & \\
\hline Total & 26.936 & 59 & & & \\
\hline
\end{tabular}

\section{Post Hoc Tests}

Multiple Comparisons

General importance of outsourcingBonferroni

\begin{tabular}{|c|c|c|c|c|c|c|}
\hline \multirow[b]{2}{*}{ (1) Management level } & \multirow[b]{2}{*}{ (J) Mngt level } & \multirow{2}{*}{$\begin{array}{c}\text { Mean } \\
\text { Difference } \\
\text { (|-J) }\end{array}$} & \multirow[b]{2}{*}{ Std. Error } & \multirow[b]{2}{*}{ Sig. } & \multicolumn{2}{|c|}{$95 \%$ Confidence } \\
\hline & & & & & $\begin{array}{l}\text { Lower } \\
\text { Bound }\end{array}$ & $\begin{array}{l}\text { Upper } \\
\text { Bound }\end{array}$ \\
\hline \multirow{2}{*}{ Middle Management } & Senior Mngt & .12463 & .18766 & 1.000 & -.3383 & .5875 \\
\hline & Top Mingt & .50558 & .27883 & .225 & -.1822 & 1.1934 \\
\hline \multirow{2}{*}{ Senior Management } & Middle Mngt & -.12463 & .18766 & 1.000 & -.5875 & .3383 \\
\hline & Top Mingt & .38095 & .29164 & .590 & -.3384 & 1.1003 \\
\hline \multirow{2}{*}{ Top Management } & Middle Mngt & -.50558 & .27883 & .225 & -1.1934 & .1822 \\
\hline & Senior Mngt & -.38095 & .29164 & .590 & -1.1003 & .3384 \\
\hline
\end{tabular}

Source: The steel retailer S.A. Outsourcing Survey

\section{Analysing Factor 3 by Race Classification within Management}

Figure 1 shows that apart from three outliers, the non-white box-plot analysis indicates a narrow spread between the $100 \%$ and nil \% margins; but with the White management, there is too wide of a spread that needs to be further analysed. 
Improvement driven reasons to outsource

Stem-and-Leaf Plots

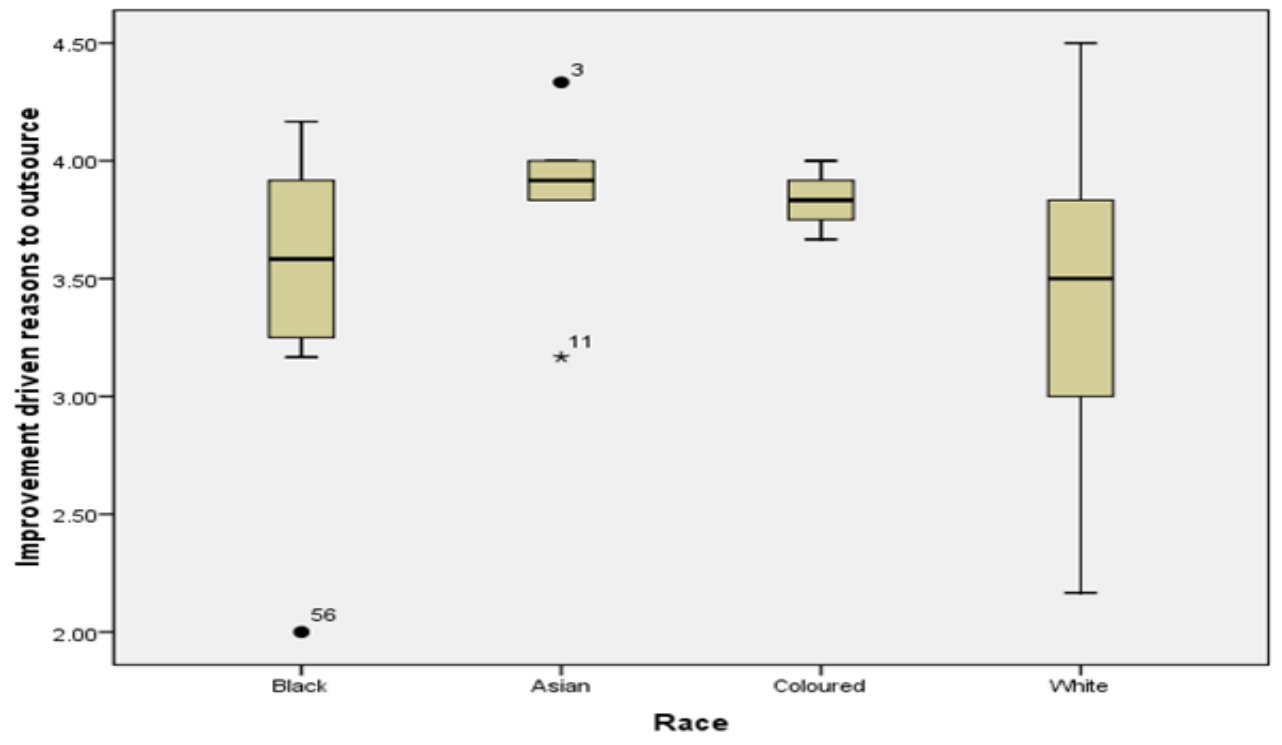

Figure 1: Data Analysis of Factor 3 by Race Classification within Management

Source: The steel retailer S.A. Outsourcing Survey

Figure 2 indicates a fairly good spread with Middle and Top Management apart from the outlier, but with Senior Management, we see too wide of a spread. There is thus significant statistical difference with White Senior management. Taken into account that there are 17 people in Senior Management from a total of 43, they can have a statistical influence on the results of White Management in general.

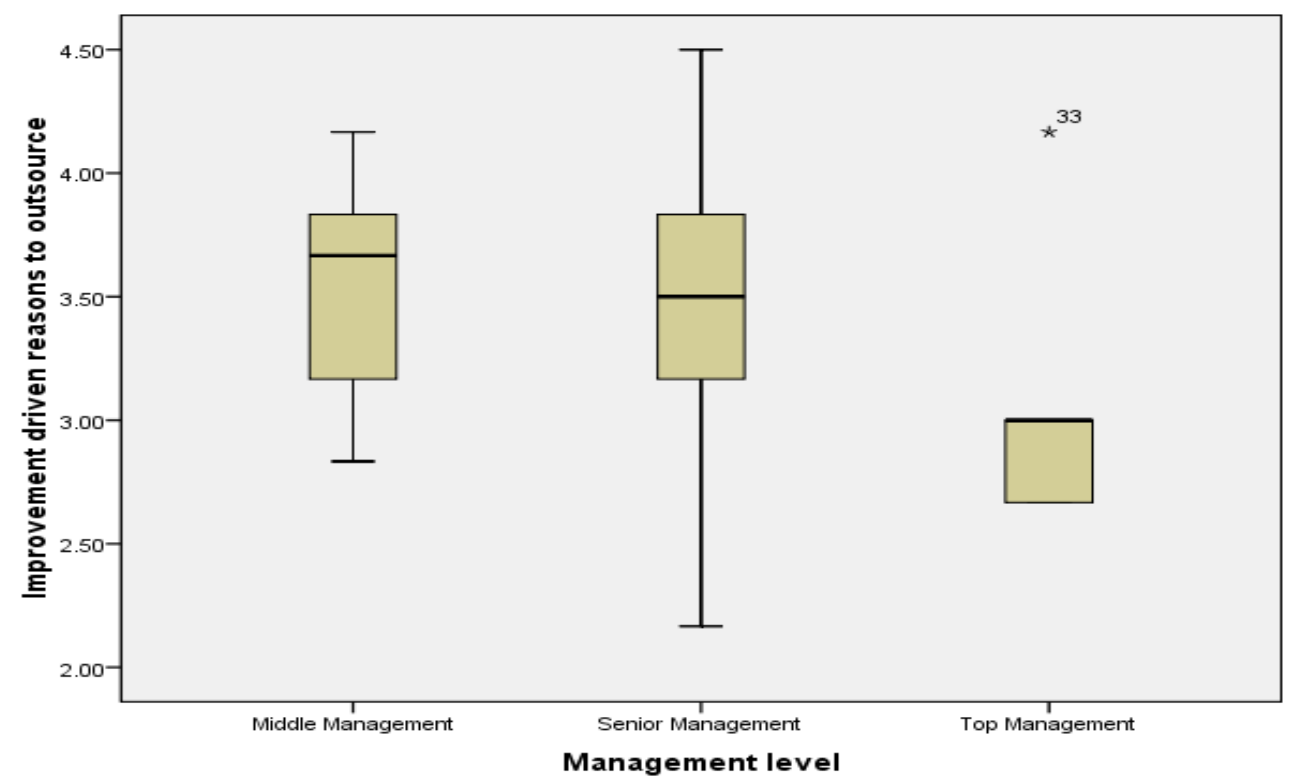

Figure 2: Data Analysis of Factor 3 for Whites by Management Level Source: The steel retailer S.A. Outsourcing Survey 


\section{CONCLUSION}

\section{Management Consensus and Perceptions on Outsourcing the Distribution Function}

General Importance of Outsourcing

An average mean score of 3.5458 (Table 5) indicates that management, in general, realizes the importance of outsourcing and acknowledges that it should and will form a part of the organization's business strategy. Middle management reflects the strongest opinion (3.65) versus that of senior management (3.52), and top management is less convincing with a score of 3.14 (a 'not sure' per the Likert scale).

Middle management, who is closer to the action on the floor, realises the benefits of outsourcing. Top management should take note of this and investigate why middle management is so much more positive toward outsourcing. This is reflected in statement 3 (Table 5) with the highest mean score of 4.1 toward freeing up management's time to focus on core competencies whilst developing current or new competencies.

\section{Organizationally-driven Reasons to Outsource}

The analysis indicates an even stronger sense of importance of outsourcing and also a much higher cohesiveness amongst all three levels of management, with senior management the most positive toward organizationally-driven reasons to outsource (with a mean score of 3.85) versus middle management (3.83) and top management (3.74), as reflected in Table 5.

The highest mean score of 4.0 attained for factor 2 reflective in statement 7 (see Figure 1) is that management should consider outsourcing in order to obtain specialized services to ensure flexibility within the organization. This reinforces management's seriousness of the role that outsourcing can play in the organization's business strategies.

Statements 5 and 8, representing 'focusing on customer needs', attracted the lowest mean scores $(3.733$ \& 3.567 per Table 5) but still indicates that management is convinced that outsourcing can improve customer relations or service levels to customers.

There are signs from the research that management is in agreement that outsourcing will enhance overall organizational effectiveness due to a better focus on core activities within the organization and the fact that specialized services can be secured through outsourcing. This, in turn, will ensure greater flexibility within the organization should it not be in a position to attract the correct skills to perform a specific function.

\section{Improvement-driven Reasons to Outsource}

From the data in Table 4, it becomes evident that factor 3 has the lowest mean score rating of all the factors (excluding factor 7) of 3.475, a very low level of Levene (0.056), and an unacceptable level of ANOVA (0.016) versus significance level of 0.05 as the minimum standard.

Indications from Table 5 are that statements $10,13,14$ and 15 have very low mean scores ('not sure') indicating management is less positive toward outsourcing improving the organization's image by linking to credible providers in the market place, improving the quality factor regarding services provided to customers, broadening the existing skills base within the organization, and improving the risks management function by transferring certain functions to service providers.

Further analysis, per Figures 1 and 2, indicates that White Management and, in particular, Top Management are less convinced toward improvement-driven reasons to outsource. From Figure 2, top management's 50th percentile is below Likert scale of 3 ('not sure'), and although senior management's $50^{\text {th }}$ percentile is just below 3.5 of the Likert scale, the $100 \%$ and nil \% are at the 4.5 and 2.2 ratings, respectively, with an outlier at 2, indicating high levels of difference in opinion amongst senior management. The research study 
revealed that of the three levels of management, in general, $16.77 \%$ of the statements per the outsource questionnaire were answered negatively toward outsourcing, $15.58 \%$ "not sure", and an overwhelming $67.75 \%$ are in agreement with utilizing outsourcing as a management tool. This indicates that the management team of the steel retailer recognizes the importance of outsourcing and the implementation therefore regarding non-core activities associated with the organization and the impact thereof on operational aspects of the business strategy.

The aim of the research was to establish whether there is consensus between top, senior and middle management on outsourcing the distribution function. The research concluded that there is no consensus between top, senior and middle management on outsourcing the distribution function. The research reflects that middle management is, overall, far more inclined to outsource than that of top management in all six factors pertaining to the questionnaires. Top Management is 'not sure' about four of the six factors, leaving the impression that they are not in favour of outsourcing. The average mean score for all management is inclined to outsource for five of the six factors and middle management six out of the six factors. This leaves the situation with a big gap between top and middle management regarding outsourcing as a management tool improving business processes and strategies.

It would thus appear that top management is too far removed from the operations and lost touch with the rest of the management team and are not acting responsibly towards the long-term future of the group.

\section{AUTHOR INFORMATION}

Professor Michael Cant is CoD Marketing and Retail Management at the university. He has published over 15 accredited articles in refereed journals and is the editor and author of more than 20 books in marketing. These books are widely prescribed at universities in South Africa. He has presented papers at more than 45 international conferences all over the world and is a well respected marketing and retail scholar. He holds a PhD in Marketing from the University of South Africa. E-mail: cantmc@unisa.ac.za. Corresponding author.

Professor L. Van Scheers is an Associate professor in marketing in the department of Marketing and Retail Management at the University of South Africa. She has a vested interest in small business research and community engagement projects.

\section{REFERENCES}

1. Atos Origin (2004): The Atos Origin Outsourcing Lifecycle - Building Successful Outsourcing Relationships, White Paper 2004, Corporate Marketing Communications, http://www.atosorigin.com/NR/rdonlyres/DD2B9DEC-E7ED-4350-896E48C2E2BE8BB8/0/wp_outsourcing_lifecycle.pdf, 22 $2^{\text {nd }}$ December 2009.

2. Baca, F. (2009): Considering HR Outsourcing? Consider SaaS, article by Fidel Baca, www.financialexecutives.org, technology, $19^{\text {th }}$ January 2010.

3. Badenhorst-Weiss, J.A. and Nel, J.D., (2008): Outsourcing Practices by the Government Sector in South Africa: A Preliminary Study, $3^{\text {rd }}$ International Public Procurement Conference Proceedings, 28-30 August 2008.

4. Beach, D.S. (1980): Personnel: The Management of People at Work, 4 ed. New York: MacMillan

5. Bendor-Samuel, P. (2000): Turning Lead into Gold (the demystification of outsourcing). South Provo: Executive Excellence Publishing.

6. BNET (2009): Business Definition for: Outsourcing, http://dictionary.bnet.com/definition/Outsourcing.html?tag=col1;rbDictionary, $5^{\text {th }}$ January 2010.

7. $\quad$ Bragg, S.M. (2004): Accounting for Payroll: A Comprehensive Guide, New Jersey: John Wiley \& Sons Inc.

8. Brewster, C. \& Tyson, S. (1991): International Comparisons in Human Resource Management, London: Pitman.

9. Burkholder, N.C., Golas, S. \& Shapiro, J. (2007): Ultimate Performance: measuring human resources at work, New Jersey: John Wiley \& Sons, Inc.

10. Burnett, R. (2008): Outsourcing IT - the Legal Aspects: Planning, Contracting, Managing and the Law, $2^{\text {nd }}$ Edition, England: Gower Publishing Limited, Google Books, Preview, $18^{\text {th }}$ January 2010. 
11. Computer World (2009): 10 Outsourcing Trends to Watch in 2010, Friday, 18 December 2009, http://www/Computerworld.com/s/article/9142427/10_Outsourcing_Trends to Watch in 2010? $5^{\text {th }}$ January 2010.

12. Corbett, M.F. (2004): The Outsourcing Revolution: Why it Makes Sense and How to do it Right, Dearborn Trade Publishing.

13. Cuming, M.W. (1989): The Theory and Practice of Personnel Management, 6ed. Oxford: Heinemann.

14. De Loof, L.A. (1997): Information Systems Outsourcing Decision Making (A Managerial Approach), London: Idea Group Publishing.

15. Dimension Data (2009): About Dimension Data, http://www.dimensiondata.com/, $8^{\text {th }}$ January 2010.

16. Fortune 500 (2009): Global 500, http://money.cnn.com/magazines/fortune/global500/2009/full_list/, $8^{\text {th }}$ January 2010.

17. Gartner (2009): Gartner Says Outsourcing will Continue to Grow in 2009 Despite Economic Slowdown, STAMFORD, Conn., $15^{\text {th }}$ January 2009, http://www.gartner.com/it/page.jsp?id=856713, $14^{\text {th }}$ January 2010.

18. Gómez-Mejia, L.R., Balkin, D.B. \& Cardy, R.L. (1998): Managing Human Resources, 2 ed. New Jersey: Prentice-Hall.

19. Gravetter, F.J., Wallnau, L.B. (2009): Statistics for the Behavioral Sciences, USA: Cengage Learning, Google Books, $31^{\text {st }}$ March 2010.

20. Gray, P.S., Williamson, J.B. \& Karp, D.A. (2007): The Research Imagination: an introduction to qualitative and quantitative ...., Google Books, Preview, $12^{\text {th }}$ January 2010.

21. Greaver, M.F. (1999): Strategic Outsourcing: A Structured Approach To Outsourcing Decisions and Initiatives, New York: AMACOM.

22. Gupta, A. (2008): Outsourcing and Offshoring of Professional Services: Business Optimization in the Global Economy, Yurchack Printing Inc, Google Books, Preview, $05^{\text {th }}$ October 2009.

23. IAOP (2009a): The Global Outsourcing 100, http://www.outsourcingprofessional.org/content/23/152/1197/, $08^{\text {th }}$ January 2010.

24. $\operatorname{IAOP~(2009b):~Top~} 10$ Outsourcing Trends to Watch for in 2010, http://www.outsourcingprofessional.org/content/23/196/1967/ , $15^{\text {th }}$ January 2010.

25. Info World (2001): Article by Mario Apicella: A Rewarding relationship with a service provider begins with a well defined SLA outlining measurable performance expectations, 30 April 2001, Google Books, $19^{\text {th }}$ January 2010.

26. Kehal, H.S. \& Singh, V.P. (2006): Outsourcing and Offshoring in the $21^{\text {st }}$ Century: a socio-economic perspective, Hershey PA: Idea Group Publishing, Google Books, Preview, $18^{\text {th }}$ January 2010.

27. Kent, R.A. (2001): Data construction and data analysis for survey research, New York: Palgrave, Google Books, $31^{\text {st }}$ March 2010.

28. Koen, P.G.L. (2002): The effectiveness and Possible Impact of Outsourcing Pertaining to the Business Operations of JCI Projects, Unpublished MBA Dissertation, Johannesburg: Milpark Business School, March 2002.

29. Leming, M.R. (2010a): Research and Sampling Designs: Techniques for Evaluating Hypotheses, Google Books, Preview, http://www.stolaf.edu/people/leming/soc371res/research.html, $13^{\text {th }}$ January 2010.

30. Leming, M.R. (2010b): Operationalization and Measurement, Sociology 371-Research Methods, http://www.stolaf.edu/people/leming/soc371res/oper.html, $13^{\text {th }}$ January 2010.

31. McIvor, R. (2005): The Outsourcing Process. Cambridge, England: Cambridge University Press: 6-36.

32. Moeketse, M.M. (2003): Outsourcing: Does it Add Value? A Case Study of the Outsourcing of Telkom's Non-core Activities, Unpublished Bachelor of Science Dissertation, Johannesburg: University of the Witwatersrand, October 2003.

33. Mol, M.J. (2004): "Outsourcing, supplier relations, and external span of control" In Proceedings, 13th IPSERA Conference (pp. 584-598). Catania, Italy.

34. Momme, J. \& Hvolby, H-H. (2002): “An Outsourcing Framework: Action Research in the Heavy Industry Sector"

35. Morgan, G.A., Gliner, J.A., Harmon, R.J. (2006): Understanding and evaluating research in applied clinical settings, New Jersey: Laurence Erlbaum Associates, Inc., Google Books, $31^{\text {st }}$ March 2010.

36. Network World (1999): Magazine Article on ASPs, 29 Nov 1999, pg 80, Google Books, $19^{\text {th }}$ January 2010. 
37. Phil Muncaster (2009): "New Research highlights a "critical" gap in managerial knowledge" Computing, Wednesday 12 August 2009, http://industry.bnet.com/technology/news-analysis/cios-failing-measureoursourcing/7276/?tag=content;col1, $22^{\text {nd }}$ December 2009.

38. Pieper, R. (1990): Human Resource Management: An International Comparison, Berlin: Walter de Gouyter.

39. Porter, M.E, (1980): “Competitive Strategy: Techniques for Analyzing Industries and Competitors”. New York: Free Press

40. $\quad$ Porter, M.E, (1998):"Competitive Advantage: Creating and Sustaining Superior Performance". New York: Free Press

41. Quickmba, (2009): Strategic Management: Core Competencies, http://www.quickmba.com/strategy/corecompetencies/, $05^{\text {th }}$ October 2009.

42. Rowley, J. (2002): Using Case Studies in Research, Management Research News, 25(1), p. 16-27.

43. Salkind, N.J. (2004): Statistics for people who (think they) hate statistics, California: Sage Publications, Inc., Google Books, $31^{\text {st }}$ March 2010.

44. Saunders, C. (2009): Systems development Life Cycle, http://www.ou.edu/class/aschwarz/Tulsa/C15Outsourcing.ppt, $22^{\text {nd }}$ December 2009.

45. Scott, A. (2009): PM Guide to Outsourcing Payroll, November 2009, http://www.peoplemanagement.co.uk/outsourcing, $19^{\text {th }}$ January 2010.

46. Seidl, R. (2007): Business Process Outsourcing Relationships in Swiss Banking: an exploratory study, Cuvillier Verlag, Google Books, Preview, $05^{\text {th }}$ October 2009.

47. Selltiz, C., Wrightsman, L., and Cook, S. (1981): Research Methods in Social Relations (4th edition), New York: Holt, Rinehart and Winston Publishers.

48. Storey, J. (1992): Developments in the Management of Human Resources, Oxford: Blackwell.

49. Sookdeo, B. (2009): Lecture Notes on Strategic Operations Management, Milpark Business School, 02 August 2009.

50. Swanepoel, B., Erasmus, B., Van Wyk, M. \& Schenk, H. (2008): South African Human Resource Management: Theory and Practice, 3 ed. Epping: Formeset.

51. Taplin, R. (2008): Outsourcing and Human Resource Management: an international survey, Routledge: Oxon, Google Books, Preview, $05^{\text {th }}$ October 2009.

52. Think180 (2008a): “Outsourcing Matrix”, http://www.think180.com/Pages/RIPs/matrix.html, 06 $6^{\text {th }}$ January 2010.

53. Think180 (2008b): "Outsourcing Lifecycle”, http://www.think180.com/Pages/FIGs/lifecycle.html, 06 January 2010.

54. Think180 (2008c): “Who Controls Sourcing?” http://www.think180.com/Pages/RIPs/whocontrols.html, $06^{\text {th }}$ January 2010.

55. Van Weele, A. (2005): Purchasing and Supply Chain Management: Analysis, Strategy, Planning and Practice, London: Thomson.

56. Vermeulen, L.M. (1998): Research Orientation: A Practical Guide for Students and Researchers, Vanderbijlpark: L.M. Vermeulen Publishers.

57. Wisner, J.D., Tan, K-C., \& Leon, G.K. (2008), (2 ed.): Principles of Supply Chain Management. Mason, $\mathrm{OH}$ : South-Western.

58. Yin, R. K. (1993): Applications of Case Study Research, Vol. 34, Sage. 